\title{
Implementation of Smoke Free Policy in the Workplace
}

\author{
Atrika Iriani $^{\mathrm{b}}$ * \\ ${ }^{a}$ Brawijaya University, Malang, East Java, Indonesia
}

\section{ARTICLE INFORMATION}

\section{Article history:}

Data submission : 10 January 2018

1st revision: 11 October 2018

Accepted: 01 December 2018

Available online: 30 December 2018

Keywords: smoke free policy, smoke exposure, workplace safety

\section{ABSTRACT}

This paper aims to explain the implementation of smoke free policy in Palembang city. The research method uses qualitative research type sourced from human instrument, event and document. Data collection technique with indepth interview, observation, and documentation. The results of this study revealed that Implementation of smoke free policy in Palembang City has been implemented but there are still obstacles in the context of implementation such as lack of human resources, and implementation of local regulation KTR (no smoking area), lack of coordination between the Head of Institution and employees and the implementation of Justice Session to KTR offenders only limited to the provision of a reprimand, no one has been given administrative sanctions. So it is still found violations committed by tenants and visitors who smoke in the region without cigarettes. Factors that support the Implementation of local regulation KTR, including: has accommodated the Implementers of Policy Implementation, Head of Agencies and Public Interest. Availability of local regulation KTR stickers or the establishment of Internal Supervisory Team in Government Agencies in order to involve all security/Security Officers without exception.

2018 FIA UB. All rights reserved.

\section{Introduction}

Smoke free policy is a policy in health as the fundamental right of every individual is declared globally in the Constitution of the World Health Organization. Based on the 1945 Constitution, Article $28 \mathrm{H}$ and law No. 36 of the year 2009 about Health, healthy and good behavior is the yearning of all people and has become the basic needs of public health degrees. Based on Government Regulation No. 19 Year 2003 regarding the safeguarding of Smoking to health, it is known that Smoking is a result of processed tobacco wrapped in, in this case, including cigars or any other form that is produced from the plant Nicotiana Tabacum, Nicotiana Rustica and other species or synthetic containing nicotine and tar with or without additional material. Research conducted by Indonesian Public Health Experties (IAKMI) mentions that 25\% (percent) smoke cigarette smoked by the smoker while the remaining $75 \%$ (percent) spread in the air and potentially sucked by other people who don't smoke or better known as passive smokers. Therefore, the application of the No-Smoking Area policy is an effective tool to reduce Second Hand Smoke (SHS) and protect the people of non smokers. Recognize the importance of protection against the hazards of smoking, it needs to be organized a form of policy that shape and substance has the power of effective practice.

In this case, specifically the city of Palembang in Indonesia has set restrictions on the smoking area for the smokers in the city of Palembang through local regulations No. 7 of the year 2009 about the NoSmoking area. No-Smoking Area is a place or room revealed banned from smoking, selling, distributing, and/ or promote smoking, include: a public place; the place of work; places of worship; children's activities arena; public transport; the area of teaching and learning; and place of health services. One of the areas without smoking in Palembang is the workplace. The smoking ban in the workplace are effective in reducing exposure to Environmental Tobacco Smoke (ETS) among employees In the area of Regulation No. 7 Year 2009 mandatory workplace apply $100 \%$ of the area without smoking in the absence of employees who smoke at work. In the city of Palembang, based on the results of a survey of compliance without smoking area which funded health services the city of Palembang in 2012 year 279 workplace, still found people who smoke of $24.7 \%$. However, after the smoking ban was implemented in the workplace, there is still a $52.2 \%$ of 
non-smoking workers were reportedly exposed to ETS exposure. Research results Fathallah et al (2012) also shows three (3) years after the enactment of the smoking ban in 2008, $30 \%$ of employees reported themselves as smokers up to the year 2010, $26 \%$ as former smokers and $44 \%$ as not smokers. Among smokers, $72 \%$ stated that they had lowered the consumption of tobacco during working hours and daily consumption of cigarettes amounting to $50 \%$. The next survey is conducted by the University of Indonesia Survey Institute in 2013 get results that only $8.5 \%$ of the city of Palembang Government offices comply with local regulations (Perda) No. 7 of the year 2009 about the NoSmoking area. The results of the Supervision exercised by the Department of health of the city of Palembang years 2014 to 149 offices in the city of Palembang Government environment there are 81 offices (54\%) who did not adhere to Perda No. 7 of the year 2009 about the No-Smoking area.

In detail, this research has a specific purpose, i.e. to analyze the implementation of smoke free in the workplace in Palembang. Expected at the end of the study, the results obtained may recommend a policy implementation model that can provide protection to the non-smoking community and law enforcement against violations of the Perda KTR in Palembang.

\section{Theory}

\subsection{Previous Research}

Islamy (1997) argued that policy is "a purpose course of action followed by an actor or set of actors in dealing with a problem or matter of concern". Furthermore Van Meter and Van Horn (1975) describe the implementation of policies as actions carried out by individuals and groups of Government and the private sector which are directed towards achieving goals and objectives that are a priority in policy decisions. The success of a policy failure or its implementation is influenced by the extent of environmental support for the policy, the availability of resources and understanding and compliance of policy makers. Hogwood and Gun (1984), divides the definition of policy failure in two categories, namely nonimplementation policies and unsuccessful implementation. The policy has the risk of failing because the implementation factor is bad execution, the policy itself is bad policy, or the policy is bad luck, to avoid the failure of the policy, it is necessary to pay attention to matters that influence policy

According to Grindle (1980), that the success of public policy implementation is influenced by two fundamental variables, namely policy content and context of implementation. These policy content variables include: (a) the extent to which the interests of the target group or target groups are contained in the content of the policy; (b) the types of benefits received by target groups; (c) the extent to which the desired change of a policy; (d) whether the location of a program is correct; (e) whether a policy has specified the implementer in detail; and (f) whether a program is supported by adequate resources. While the policy environment variables include: (a) how much power, interests, and strategies are owned by actors involved in policy implementation; (b) the characteristics of the institutions and regimes in power; and (c) the compliance and responsiveness of the target group.

There are many benefits of providing a smoke-free workplace. In addition to meeting the legal obligations and eliminating the risk of prosecution for noncompliance in relation to enclosed workplaces, a smokefree policy can: Provide a safer, cleaner and healthier workplace environment, Encourage and support smokers to cut down or quit, Educate staff on the health risks of smoking, and of the benefits of quitting, Promote a healthy corporate image, Increase productivity, Reduce absenteeism from illness caused by smoking and passive smoking, Reduce cleaning and maintenance costs, Reduce the fire risk and also Reduce the risk of litigation/ compensation costs resulting from passive smoking caused illness.

\section{Research Method}

This type of research is qualitative research, i.e. research which is used to test the condition of the object where the researcher is key instrument. Based on the type of data and analysis, this research is descriptive qualitative, aiming to describe and analyze the implementation smoke free policy in the workplace Palembang, i.e:

a) Content of policy include Interest Affected, Type of Benefits, Extent of Change Envision, Site of Decision Making, Program Implementer and Resources Committed; and

b) Context of Implementation, i.e. Power, Interest, and Strategy of Actor Involved; Institution and Regime Characteristic; Compliance and Responsiveness.

Data collection techniques used in this research are:

a) Interview

Interviews were conducted with the purpose of data collection is complete, in-depth and accurate so that helps researchers to analyze the problems of research in a more incisive about the process of the implementation smoke free policy.

\section{b) Observation}

The observation is done with regards to implementation smoke free policy in the workplace Palembang.

\section{c) Documentation}

Analyzing the books or literature relating to research especially, health service archive in the city of Palembang, documentation, as well as journals relating to the compliance of the implementation smoke free policy in the workplace Palembang.

The source of the Data used in this study include:

\section{a) Informant}

Informants in this study include: Head and Employee of Health Office in Palembang City, Head and Employee of Pamong Praja (Civil Service) in Palembang City, the Enforcement Team of Perda KTR, and interview to Leaders and Officials of Government Institution apply smoke free policy in the workplace Palembang. 


\section{b) Places and Events}

Sources of data obtained at Government Agencies that serve as a place of study, as well as activities of supervision activities, the provision of facilities are of smoke free policy of employees and forms of violations and sanctions provided.

c) Documentation relevant to the research problem that is the Regional Regulation No. 7 Year 2009 About No Smoking Area of Palembang City, Regulation of Mayor of Palembang No. 18 of 2010 on the Control of Non-Smoking Areas, guidance on the implementation of supervised activities, reports on the implementation of activities and other documents considered important in this research.

The analysis technique used in this research is qualitative data analysis technique. According to Miles, Huberman and Saldana (2014), in the analysis of qualitative data there are three activities that occur simultaneously. Activities in data analysis, namely: Data Condensation, Data Display, and Conclusion Drawing/ Verifications. The data analysis techniques used in research on implementation smoke free policy in the workplace Palembang.

\section{Results and Discussion}

Perda No. 7/2009 on Non-Smoking Area in Palembang City, in accordance with the vision of clean Palembang (clean air, water and land). Therefore, the government needs to reduce the number of smokers, or at least regulate where smokers should smoke so as not to interfere with the comfort of those around them who do not smoke. The Non-Smoking Area is a place or room that is not allowed to smoke, sell, advertise, and/ or promote cigarettes, including: public places; workplace; worship place; children's playground; public transport; a place of learning; and health services. Determination of Non Smoking Areas aims to:

a) Provide effective protection against the dangers of exposure to other people's smoke;

b) Providing clean and healthy space and environment for the Community; and

c) Protect public health in general from the negative effects of smoking, either directly or indirectly.

The principle of Determination of Non Smoking Area are:

a) $100 \%$ non-smoking area;

b) No smoking rooms in public areas or closed workspaces; and

c) The exposure of secondhand smoke to others through smoking, or the act of allowing or allowing people to smoke in non-smoking areas is against the law.

The Technical Guidance on the Implementation of Supervision of Non-Clandestine Area is in accordance with the Mayor of Palembang Regulation No. 67 of 2010 Article 6, the Non-Cigarette Regulatory Team performs its duties with the following guidelines:

a) Put signs of smoking bans at all major entrances and places where they are necessary and readable;

b) Remind everyone to not smoke in public;

c) Prohibits smoking in public places; d) Prohibits smoking in public places;

e) Prohibits selling or advertising or promoting cigarettes that do not conform to their permission;

f) Prohibits the existence of ashtrays;

g) Report a violation to the KTR Executing Team;

h) Coordinate with the implementing supervisory team; and

i) Report regularly every 3 months.

Within a period of one (1) year from the enactment of this Regulation, every Owner, Manager, Manager, Leader, and Responsible Area Without Cigarettes, shall make adjustments with the provisions of this Regulation. Violation of the provisions of this Regional Regulation shall be punishable by a penal code of imprisonment of no more than 3 (three) months or a maximum fine of $\mathrm{Rp}$. 50.000.000, - (fifty million rupiah).

Based on the Policy Content analysis, it is evident that the public interest in this regard is known that everyone is entitled to clean air and enjoy air free from cigarette smoke and is entitled to correct information and education about smoking or smoking and the dangers to health. Therefore, everyone is required to maintain a clean and healthy environment free of cigarette smoke in the room or area declared area without smoking. In the Policy Content always refers to whether the implementation of the policy in accordance with the determined by seeing the action of the policy. The indicators that can measure the content of the policy are a) Interests Affected, b) Type of Benefits, c) Extent of Change Envision, d) Site of decision making, e) Program Implementer, f) Resources Committed. The following table describes the contents of the Policy pursuant to the Articles stated in the Regional Regulation No. 7 Year 2009 About Non Smoking Area in Palembang City.

Interest affected deals with the various interests that support and impede a policy implementation. This indicator argues that a policy in its implementation must involve many interests and the extent to which those interests have an effect on its implementation. Various interest groups, including civil society, play a more important role in shaping and delivering public health policies at both national and international levels in many countries. Although in this process public health policy making is more complex and less predictable, Mays. Based on the Regional Regulation of Palembang City. 7 of 2009 concerning Non Smoking Areas, the Interests affected in the implementation of the policy of nonsmoking areas in the Government Institutions of Palembang City, include: Implementing Policy Implementation of Non-smoking Areas, Interests of Palembang City Government Institutions and Public Interest. Based on the findings of the research, it is known that in the implementation of the non-smoking area policy in Palembang City has included the interests of the target groups in the policy content. It can be seen from Regional Regulation of Palembang City about KTR which is a form of protection against those who do not smoke; create a healthy environment; as well as curbing active smokers where he smokes instead of forbidding those who smoke. This KTR law has sought to educate the public and make it clear that everyone has the right to breathe clean air. So for them the smokers should be orderly, must know where they smoke. 
Type of Benefits in the Policy Contents attempt to show or explain that in a policy must have some kind of benefits that show the positive impact generated by the implementation of the policy to be implemented. In the regulation of public health policy, regulators can develop guidelines, make recommendations, and make decisions to help the community. This policy also serves to explain how the regulator thinks and makes decisions. Decisions in written policy can help to encourage international harmonization, different policies or procedures may be discussed, rationalized (ie, examination of the scientific reasons given), in harmony, Sheets. The findings of the research found that in the implementation of the policy of non-smoking areas in Palembang City has had positive benefits, such as the creation of non-smoking areas in 7 Regencies of Palembang City, thus making the workplace environment comfortable because the air is clean from the pollution of cigarette smoke and the decrease of the number of smokers so it can improve the health of employees/ community.

\subsection{Extent of Change Envision}

Every policy has a target to be and wants to achieve. The content of policy to be explained at this point is that how much of a change one wants or wants to achieve through a policy implementation must have a clear scale. Implementation of a non-smoking area policy may have a small but profitable impact on smoking cessation efforts, Barbara, et all. In Uruguay, the implementation of $100 \%$ smoke free area has been shown to reduce emergency care to hospitals, especially inpatient care for bronchospasm. So the policy of a nonsmoking area is strongly recommended especially for countries with the majority of low and middle income population to reduce the burden of disease and health costs related to smoking, Kalkhoran, et all. Based on the above description can be said that the policy area without smoking is strongly recommended, especially for countries with the majority of low and middle income population to reduce disease burden and health costs related to smoking. In this case the degree of change to be achieved in the implementation of smoke free policy in the city of Palembang, among others, the creation of $100 \%$ area without cigarette smoke, no smoking room closed and no cigarette exposure to others through smoking, or the act of allowing and or allowing People smoke in smoke free Areas.

Site of Decision Making in a policy plays an important role in the implementation of a policy, then in this section should be explained where the location of the decision of a policy to be implemented. Decisions are an option made from two or more alternatives. Based on the findings of the research, it is known that the location of decision making in the implementation of the policy of non-smoking area in Palembang City, is at the Health Office of Palembang City which oversees and the Civil Service Police Unit as the Law Enforcement Team. In order to implement a nonsmoking area policy, an Internal Supervisor or the Law Enforcement Team of regional regulation about KTR (usually consisting of the Security Guard) should coordinate with the Regional Leader or Management, who will monitor the security as well as secure those who smoke both visitors and owners of tenants.
Implementer programs should be supported by a competent and capable policy implementer for the success of a policy. Monitoring compliance with NonCigarette Rules Regulations can help identify weaknesses in the law enforcement system. Once identified, resources can be transferred and additional training can be provided to Policy Implementers to help improve overall enforcement and compliance, Lambert and Donley. Based on the findings of the research, it is known that the implementer of the non-smoking area policy in Palembang City includes the Implementing Team of Non-Smoking Area Supervisory City of Palembang consisting of the Mayor and his staff as the director and the Health Office of Palembang City and the Head of the Municipal Police Unit as the executor by involving the Agency related. Implementing a nonsmoking area policy is competent and capable in performing its duties that have carried out coaching, supervision and coordination and evaluation.

\subsection{Resources Committed}

In this case the implementation of a policy must also have resources that support for the implementation of the policy goes well. The implementation of KTR is carried out by Sat Pol PP helping the Health Office implement enforcement of KTR Regulation. The Regional Regulation about KTR Enforcement Survey has been implemented frequently. Sat Pol PP officers involved in enforcement of the KTR law include the enforcement of other local regulations. Personnel in Sat Pol PP as Law Enforcement KTR legislation is enough. In carrying out their duties are also given tired money to motivate personnel. Survey results are accompanied by enforcement images of Regional Regulation about KTR. In this case Surveys and Justice Sessions are usually held on Tuesday, at locations that have been determined on schedule. The sources of finance for the implementation of the non-smoking area policy are sourced from APBN MOH, APBD and Fund Support from: World Lung Foundation and Union, the Fund is used to make stickers of Regional Regulation about KTR which will be distributed free of charge to 7 Regions without Cigarettes, and Funds for the enforcement of law enforcement surveys Regional Regulation about KTR of 9.3 million given to Sat Pol PP. It is known that the funds used are very limited considering the place to be surveyed is also quite a lot. In addition, the implementation of Regional Regulation about KTR is still lacking facilities in the form of public complaints about violations of the Regional Regulation and the provision of free Health Clinic for Smokers to stop smoking.

In the Policy Context always refers to whether the implementation of the policy in accordance with that determined by seeing the action of the policy. The indicators that can measure the content of the policy are a) Power, Interest and Strategy of Actor Involved; b) Institution and Regime Characteristic; and c) Compliance and Responsiveness.

\subsection{Power, Interest and Strategy of Actor Involved}

In a policy to be taken into account include the power or power, interests and strategies used by the actors involved in order to facilitate the implementation of an implementation. Based on the findings of the 
research, it is known that the strategy of the actors involved in the implementation of the Non-Smoking Area Policy, among others includes the implementation of socialization, Air Quality Monitoring check activities, newspaper clippings related to cigarettes, smoke free area with assistant 4 and the legal part of the city government and training of Law Enforcement Team of Regional Regulation KTR. Also conducted Surveys and Trials Justice in front of the International Plaza by using a Mobile Car from the Police Unit of the City of Palembang. But for the Government Institution it self has not been maximized. So based on the results of the description can be said that the strategy of actors involved in the implementation of the policy area without smoking, not maximized. 7 areas designated as Non Smoking Area just put sticker smoking ban only. The KTR law is not announced through the Information section, so not all people know about the KTR rule. The implementation of the Justice Session to the KTR offenders is limited to giving a reprimand only, no administrative sanction has been granted.

\subsection{Institution and Regime Characteristic}

The environment in which a policy is implemented also affects its success. Based on the findings of the research note that, in enforcing the law of KTR in Palembang City, at that time there was not one ashtray nor people who smoke. So the Team from Sat Pol PP cannot take legal action, to the Leader/ Manager. In the case of violations found outside the inner environment, but still in the IP environment, the violators that we do/ we do the coaching. In this case we make the news event so that the concerned does not smoke. But at the time the survey has not occurred. It is therefore expected that the enforcement of the KTR Law not only involves the competent authorities, as well as the Internal Supervisors but also involves all levels of society by providing complaints against violations of the KTR Regulation. The adoption of the smoke free Policy as an effort to build self-awareness and enforceable by the public, notes that in many jurisdictions, public complaints are the primary means of ensuring compliance. In addition, to facilitate law enforcement by the Public, the WHC FCTC guidelines recommend establishing a toll-free telephone number that can be used by the public to report a violation to the relevant Government. Based on the above discussion, it can be said that Characteristics of institutions and regimes in power and environment in implementing the Regional Regulation No. 7 Year 2009 About Non Smoking Area in Palembang City, not yet conducive enough.

\subsection{Compliance and Responsiveness}

In this case the extent of compliance and response of the implementers in response to a policy. Employee compliance in the implementation of non-smoking area policy in Palembang City Government Institution include: predisposing factors, generally employees have been aware of KTR regulation, but there are still many employees who do not care so that commitment to obey the law of KTR not yet exist, so the behavior of smoking specially in the Office (Government Agencies) continues to occur, so self-regulation and attention to cultural and social contexts are important in shaping smoking behavior and finding changes in smoking behavior in public places. In aspects of enabling factors in the form of provision of facilities one of them in the form of free Clinic for Smokers. as well as public complaints facilities about violations of Regional Regulation KTR still felt less than the maximum. To understand that habit smoking is a chronic dependency that can recur, a Therapy Program approach that can be implemented in a short time at the Outpatient Clinic and discusses the use of nicotine replacement therapy. In the aspect of the reinforcement factor, the application of sanction is still limited to the provision of Warning Letter (SP1 and SP2). Data can be seen in the following table (Table 1 and Table 2):

Table 1. List of SP1 Recipients Against Violation of 2016 KTR Area Rules

\begin{tabular}{|c|c|c|c|}
\hline No. & Instansi & No. & Instansi \\
\hline 1 & District Office Sako & 15 & Subdistrict Office 3 Ilir \\
\hline 2 & $\begin{array}{l}\text { District Office } \\
\text { Sukarami }\end{array}$ & 16 & $\begin{array}{l}\text { Subdistrict Office } \\
\text { Kemas Rindo }\end{array}$ \\
\hline 3 & District Office Kalidoni & 17 & $\begin{array}{l}\text { Subdistrict Office } \\
\text { Bagus Kuning }\end{array}$ \\
\hline 4 & $\begin{array}{l}\text { District Office } \\
\text { Sematang Borang }\end{array}$ & 18 & $\begin{array}{l}\text { Subdistrict Office } 23 \\
\text { Ilir }\end{array}$ \\
\hline 5 & $\begin{array}{l}\text { Subdistrict Office } \\
\text { Keramasan }\end{array}$ & 19 & $\begin{array}{l}\text { Subdistrict Office } 1 \\
\text { Ulu }\end{array}$ \\
\hline 6 & Subdistrict Office Sako & 20 & $\begin{array}{l}\text { Subdistrict Office } 2 \\
\text { Ulu }\end{array}$ \\
\hline 7 & $\begin{array}{l}\text { Subdistrict Office Sako } \\
\text { Baru }\end{array}$ & 21 & $\begin{array}{l}\text { Subdistrict Office } \\
\text { Srilaberanti }\end{array}$ \\
\hline 8 & $\begin{array}{l}\text { Subdistrict Office } \\
\text { Sukamaju }\end{array}$ & 22 & $\begin{array}{l}\text { Subdistrict Office } 20 \\
\text { Ilir }\end{array}$ \\
\hline 9 & $\begin{array}{l}\text { Subdistrict Office } \\
\text { Sukamulya }\end{array}$ & 23 & $\begin{array}{l}\text { Subdistrict Office } 18 \\
\text { Ilir }\end{array}$ \\
\hline 10 & $\begin{array}{l}\text { Subdistrict Office } 5 \\
\text { Ulu }\end{array}$ & 24 & Subdistrict Office 2 Ilir \\
\hline 11 & $\begin{array}{l}\text { Subdistrict Office } 8 \\
\text { Ulu }\end{array}$ & 25 & $\begin{array}{l}\text { Subdistrict Office Pipa } \\
\text { Reja }\end{array}$ \\
\hline 12 & $\begin{array}{l}\text { Subdistrict Office } \\
\text { Tangga Takat }\end{array}$ & 26 & $\begin{array}{l}\text { Subdistrict Office Ario } \\
\text { Kemuning }\end{array}$ \\
\hline 13 & $\begin{array}{l}\text { Subdistrict Office } \\
\text { Sukabangun }\end{array}$ & 27 & $\begin{array}{l}\text { Subdistrict Office } \\
\text { Lorok Pakjo }\end{array}$ \\
\hline 14 & Subdistrict Office 9 Ilir & 29 & $\begin{array}{l}\text { Subdistrict Office } \\
\text { Pahlawan } \\
\text { Subdistrict Office } \\
\text { Kertapati }\end{array}$ \\
\hline
\end{tabular}

Source: Public Health Office, 2016

Table 2. List of SP2 Recipients Against Violation of 2016 KTR Area Rules

\begin{tabular}{cl}
\hline No. & \multicolumn{1}{c}{ Instansi } \\
\hline 1 & District Office Sako \\
2 & District Office Sukarami \\
3 & District Office Kalidoni \\
4 & District Office Sematang Borang \\
5 & Subdistrict Office Keramasan \\
6 & Subdistrict Office Sako \\
7 & Subdistrict Office Sako Baru \\
8 & Subdistrict Office Sukamaju \\
9 & Subdistrict Office Sukamulya \\
10 & Subdistrict Office 5 Ulu \\
15 & Subdistrict Office 3 Ilir \\
16 & Subdistrict Office Kemas Rindo \\
\hline
\end{tabular}




\begin{tabular}{cl}
\hline No. & \multicolumn{1}{c}{ Instansi } \\
\hline 17 & Subdistrict Office Bagus Kuning \\
18 & Subdistrict Office 23 Ilir \\
19 & Subdistrict Office 1 Ulu \\
20 & Subdistrict Office 2 Ulu
\end{tabular}

Source: Public Health Office, 2017

In this case, direct face-to-face techniques, the establishment of the Internal Supervisory Team as well as the implementation of strict supervision and sanctions, are expected to improve compliance in Implementation of non-smoking area policy in Palembang City. Here is a picture of smoke free policy socialization and an employee who violates the KTR Law of Palembang by smoking in the workplace (Figure $1-3)$.

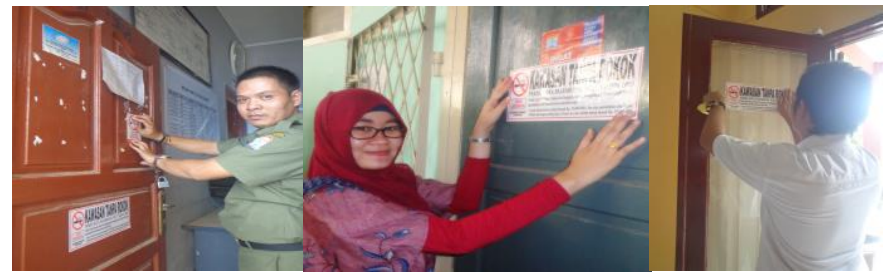

Figure 1. Satpol PP Staf, \& Researcher attaching smoke free policy sticker in Palembang City Government Institution

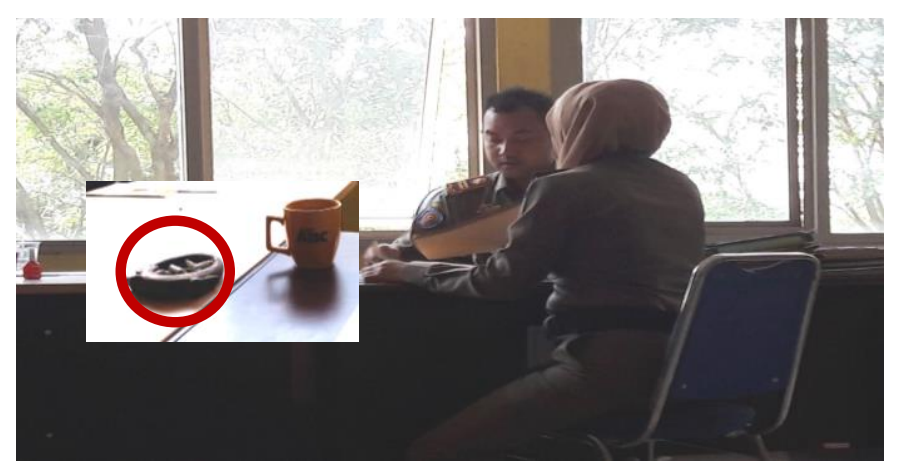

Figure 2. Satpol PP Staf in Violation of KTR regulation of Palembang City

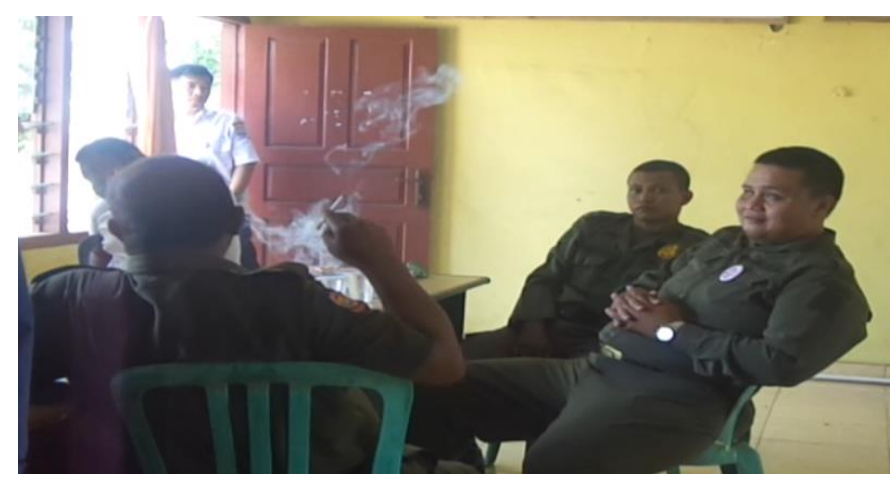

Figure 3. Government Employee in Violation of KTR Regulation of Palembang City

In every country, the percentage of employees working in smoke-free workplaces reported living in smoke-free homes is higher than those who work in non-smoke-free workplaces. In LMICs, work at a smoke-free workplace is linked to staying in a smokefree home. Accelerating the implementation of a comprehensive non-tobacco-free policy is likely to result in substantial population health benefits in this setting, Nazar, et al (2014).

\section{Conclusion}

Based on the content policy, the establishment of Internal Supervisory Team and Law Enforcement of smoke free policy in Government Institutions can not cover all KTR areas at all times, the level of awareness of both employees and communities receiving services to comply with the KTR Regulation is still low. Therefore, the implementation of smoke free policy needs to determine who has the authority to carry out inspections and the authorities impose sanctions, monitor compliance and strengthen law enforcement. In addition, self-awareness, in this case the public also plays an active role in the implementation of smoke free policy. Based on the implementation context, the strategy of the actors involved for the Government Institution itself has not been maximized. In Government Agencies just put sticker smoking ban only. Therefore, it is necessary to socialize and enforce the law of the Regional Regulation of the KTR including penalties for violation of duties imposed covering administrative penalties as well as criminal sanctions. Furthermore, the compliance of employees in the implementation of smoke free policy in the Government Institutions of Palembang City, including: predisposing factors, the employees have been aware of the KTR law, but there are still many employees who do not care so that commitment to obey the KTR regulation has not existed, especially in the Office (Government Agencies) is continuous, so self-regulation and attention to cultural and social contexts is important in shaping smoking behavior and finding changes in smoking behavior in public places. In aspects of enabling factors in the form of provision of facilities one of them in the form of free Clinic for Smokers Smoking to stop smoking. as well as public complaints facilities about violations of Perda KTR still felt less than the maximum. To understand that habit smoking is a chronic dependency that can recur, a Therapy Program approach that can be implemented in a short time at the Outpatient Clinic and discusses the use of nicotine replacement therapy. In the aspect of the reinforcement factor, the application of sanction is still limited to the provision of Warning Letter (SP1 and SP2). In this case, direct face-to-face techniques, the establishment of the Internal Supervisory Team as well as the implementation of strict supervision and sanctions, are expected to improve compliance in Implementation of smoke free policy in Palembang City.

\section{References}

Fathallah, N., Maurel-Donnarel, E., Baumstarck-Barrau, K., \& Lehucher-Michel, M. P. (2012). Three-year Follow-up of Attitudes and Smoking Behaviour Among Hospital Nurses Following Enactment of France's National Smoke-free Workplace Law. International Journal of Nursing Studies, Vol. 49(7), pp.803-810.

Grindle, Marille, S. (1980). Politics and Policy Implementation in The Third World. New York: Princeton Unversity Press.

Hogwood, Brian W., and Lewis A. Gunn. (1984). Policy Analysis for The Real World. Oxford: Oxford University Press. 
Miles, M. B., Huberman, A. M., \& Saldana, J. (2014). Qualitative Data Analysis: a Method Sourcebook. CA, US: Sage Publications.

Islamy, Irfan. (1997). Prinsip-Prinsip Perumusan Kebijakan Negara. Jakarta: Bumi Aksara.

Nazar, Gaurang P, et al. (2014). Association Between Being Employed in a Smoke-Free Workplace and Living in a Smoke-Free Home: Evidence From 15 Low and Middle Income Countries. Preventive Medicine, Vol. 59(100), pp.47-53.

Van Meter, Donald S., and Carl E. Van Horn. (1975). The Policy Implementation Process: A Conceptual Framework. Administration and Society, Vol. 6, pp.445-88. 